\title{
5D OF BIM - RESEARCH STUDIES AT HOME AND SLECTED COUNTRIES AROUND THE WORLD
}

\author{
Jana Smetanková \\ Technical University of Košice, Faculty of Civil Engineering, Department of Construction Technology and \\ Management, Vysokoškolsk 4, 04200 Košice, Slovakia, jana.smetankova @ tuke.sk (corresponding author) \\ Annamária Behúnová \\ University of Košice, Faculty of Manufacturing Technologies with a seat in Prešov, Bayerova 1, 08001 \\ Prešov, Slovakia, annamaria.behunova@tuke.sk \\ Tomáš Mandičák \\ Technical University of Košice, Faculty of Civil Engineering, Department of Construction Technology and \\ Management, Vysokoškolsk 4, 04200 Košice, Slovakia, tomas.mandicak@tuke.sk

\section{Peter Mesároš} \\ Technical University of Košice, Faculty of Civil Engineering, Department of Construction Technology and \\ Management, Vysokoškolsk 4, 04200 Košice, Slovakia, peter.mesaros@ tuke.sk
}

Keywords: building information modelling, 5D, cost, implementation, cost management tools

Abstract: Currently time is characterized as a stage of dynamic progress and expanding use and implementation of information and communication technology generally. Data and information about cost and budgeting are required in the knowledge society heads grow every day. Several studies suggest that the use of Building information modelling (BIM) and cost management tools contributes on cost reducing of project and enterprise management. However, these studies also indicate that their use in small and medium sized enterprises is low. Several surveys have been carried out abroad on this issue. The exploitation of Building information modelling to support cost management in many enterprises is a priority and one of the main steps and procedures to successfully manage enterprises and construction projects. Building infomration modelling and cost management tools are one of the possible solutions for cost reducing. Article discusses issue of possibility to use cost management tools and Building information modelling in Slovak construction industry and abroad from various point of view. The main objective of this article is to make an overview of using BIM technology and cost management tools at home and abroad. The paper also aims to point to new research opportunities and to identify research issues in this area.

\section{Introduction}

Building information modelling is the process of creating and data managing about the building during its life cycle. According to National Institute of Building Science (NIBS, 2015), digital model represents a physical and functional object with its characteristics and specifics. It serves as an open database of information about the object for its execution and construction in all lifecycle [1].

BIM model is more than $3 \mathrm{D}$ model. BIM is common data environment. The common data environment can be divided on Figureical and non-Figureical information. According to BIM principles there exists 7 established dimensions, which are:

- 3D - geometry,

- 4D - time,

- $5 \mathrm{D}$ - costs,

- 6D - sustainability,

- $\quad 7 \mathrm{D}$ - facility management [2].

Building Information Modelling (BIM) and automated quantities technologies provide both enormous opportunities and challenges for the project cost management profession.
Fifth dimension is used for budget tracking and cost analysis. Creating a construction budget is one of the most important parts of the life cycle of a project. Determining the amount of costs is demanding in terms of the quality of the documents provided and the method of budgeting [3].

The fifth dimension of BIM - costs bring a lot benefits for example better visualization construction, improvement collaboration on projects, increase project quality and BIM Data Quality, increase project conceptualization, increase efficiency of Take-offs, increase efficiency of Cost Planning, earlier risks identification and other [4].

\section{D BIM -tracking and cost management tool}

Exploitation of computers and software has increased productivity and speeded up of processes. In fact, more than 55\% of estimates fail due to insufficient software solutions in estimating process. The best software solutions may not be complicated or costly in cost management and estimating process. It must meet the following conditions in particular:

- data import tool, 
- $\quad$ an integrated cost database (custom pricelists or company data compared to commercially available data),

- a cost estimating tool [5].

The construction market is aware of the merits of eliminating errors caused by incorrectly compiling the report, which will then be transferred to the actual pricing, so there is an increasing supply of software applications for the creation of calculations, budgets, and quotes. The overview of software tools supporting 5D BIM and their use in countries is shown in Table 1.

Table 1 Overview of software application

\begin{tabular}{|c|c|c|}
\hline $\begin{array}{l}\text { Software } \\
\text { application }\end{array}$ & Company & Use in countries \\
\hline $\begin{array}{c}\text { Cubit } \\
\text { Buildsoft }\end{array}$ & Australia & $\begin{array}{c}\text { Australia, New Zealand, United } \\
\text { Kingdom, Ireland }\end{array}$ \\
\hline $\begin{array}{c}\text { Nevaris } \\
\text { Nemetschek }\end{array}$ & Germany & Germany, Switzerland, Austria \\
\hline $\begin{array}{l}\text { Exactal } \\
\text { COST X }\end{array}$ & $\begin{array}{l}\text { United } \\
\text { Kingdom }\end{array}$ & $\begin{array}{l}\text { worldwide (Europe - United } \\
\text { Kingdom, Ireland) }\end{array}$ \\
\hline $\begin{array}{l}\text { INNOVAYA } \\
\text { Visual } \\
\text { Estimating } \\
\end{array}$ & USA & USA \\
\hline BIM estiMate & Poland & Poland \\
\hline $\begin{array}{l}\text { Vico Cost } \\
\text { Planner }\end{array}$ & USA & $\begin{array}{c}\text { worldwide (Europe - United } \\
\text { Kingdom, Sweden, Asia, } \\
\text { Australia) }\end{array}$ \\
\hline $\begin{array}{c}\text { Gala } \\
\text { Construction } \\
\text { Software } \\
\end{array}$ & Croatia & Croatia \\
\hline iTWO 4.0 & Germany & $\begin{array}{c}\text { Austria, Cyprus, Czech Republic, } \\
\text { Denmark, Germany, Slovakia, } \\
\text { Spain, Switzerland, Great } \\
\text { Britain, Ireland }\end{array}$ \\
\hline $\begin{array}{l}\text { Synchro } \\
\text { Software }\end{array}$ & USA & $\begin{array}{l}\text { worldwide (Europe - United } \\
\text { Kingdom) }\end{array}$ \\
\hline Calcus & Norway & Norway \\
\hline
\end{tabular}

Building information modelling brings many benefits. Many countries have implemented BIM in their laws and standards and research about state of implementation BIM was applied. In this chapter is presented overview to realised researches oriented on state of implementation fifth dimension - 5D costs, in selected countries.

\subsection{New Zealand and Australia}

Organisation Masterspec conducted national BIM (New Zealand) survey found that the proportion of BIM users increased from $34 \%$ (2012) to $57 \%$ (2013), with a year-on-year increase in overall BIM awareness in the construction industry, from $88 \%$ (2012) to $98 \%$ (2013) [6].

New Zealand's BIM maturity level remains fairly rudimentary, and most of the industry is still operating at Stage 1B ('Intelligent 3D') of the Australian Institute of Architects' BIM implementation scale [7].
5D BIM is rarely being implemented in New Zealand, except on a very few large projects, which have recently used a single integrated BIM model, which can be shared with other project participants [8]. A recent survey of 20 quantity surveyors in New Zealand found that almost all respondents had experienced no more than 5 projects which had used 5D BIM [9]. Despite the purported benefits of BIM, the adoption of 5D BIM in New Zealand and Australia is significantly slow-moving due to a number of barriers limiting its implementation within industry, which are ultimately centred around the fragmented nature of the construction industry, suggesting that a shift in current workflows is required [6,10].

In 2014 Dr. Peter Smith conducted a research called BIM and project cost management - implementation issues and creative solutions. Results revealed that there are considerable implementation issues. This research presented these findings:

- the quality of the BIM models (nevertheless, an increasing number of firms are utilizing 5D BIM tools),

- the technology is always evolving and the interviewees commented that a lot of time and expense can be spent on software and training with uncertain outcomes,

- lack of Standards/software incompatibility,

- $\quad$ sharing cost data information [11].

Respondents interviewed used automated quantities software to prepare quantities on their projects. Four of the firms used this software extensively particularly in the cost planning stages whilst the other two firms used such software in a limited capacity. The firms used both proprietary and in-house software with the CostX program the most commonly used program [11].

\subsection{Iceland and Scandinavia}

The Scandinavian region has a strong BIM development and implementation track record. In publication Implementation of BIM, Elvar Ingi Jóhannesson focused on comparing implementation of BIM on Island and in Scandinavian countries. In this comparison, Jóhannesson focused on using BIM in various fields, for example marketing, facility maintenance, cost estimation, scheduling and other [12].

Jóhannesson focused on comparing implementation of BIM on Iceland and in Scandinavian countries. BIM's rate of utilization in cost estimating is higher in Scandinavian countries $-14 \%$.So are interesting tendering and quantity take-off data's. Also in this case Scandinavian countries are in the foreground - tendering $9 \%$ and quantity take-off $18 \%$ (Figure 21)[12]. 


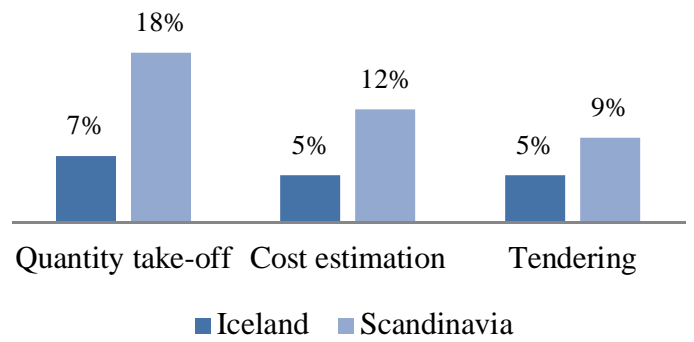

Figure 1 Use of information modeling of buildings - comparison Iceland and Scandinavia [12]

\subsection{United Kingdom}

Important country on European and world forum is Great Britain. In 2011, British government released a document of labor groups interested in strategies of implementation and using BIM. Also government expressed an intention, that since 2016 it will require using BIM tools for all drafts for public contracts. Great Britain created National BIM Library (NBL), where it offers more than 350 constructing presets (walls, ceilings, windows, doors, etc.), products from different producers. Library is constantly extending, therefore strategy of BIM's implementation support in British civil engineering industry is supported [13].

$\square$ Never Occasionally $\square$ Often

Operation \& management

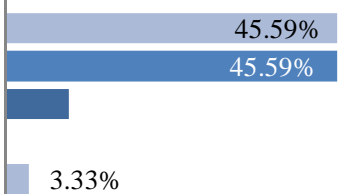

\section{Construction \\ Preconstruction (Detail design \& Tender)}

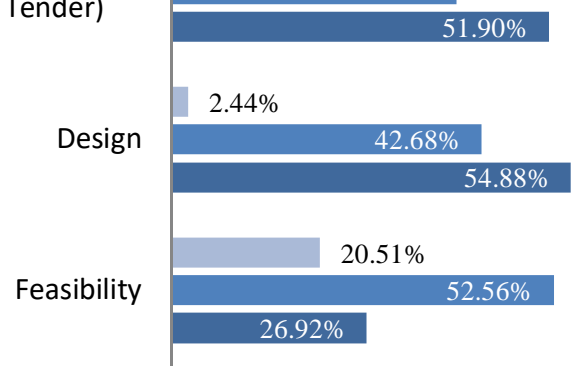

Figure 2 The use of BIM software tools [14].

In 2016, Software Advice analyzed small and medium organizations and their needs. Key discoveries from this survey are follow:

- $\mathbf{6 0 \%}$ seeks in this software options for estimate of construction costs

- $\quad \mathbf{2 4 \%}$ wants to increase project's transparency and to upgrade its monitoring
- $\mathbf{5 0 \%}$ currently use manual methods for computing costs, offers preparation and managing projects [15].

Robert Eadie's et. al. conducted research under name of BIM Implementation throughout the UK construction project lifecycle: An analysis. Following the results, software tools supporting information modeling of buildings are used mostly in design $(54,88 \%)$ and occasionally in realization (Figure 2 ). In process of pricing and detail design, information modeling is used often, in $51,90 \%$ cases, $39,24 \%$ occasionally and only $8,84 \%$ is not using it [14].

\subsection{Slovakia}

At present, there are a number of specialized programs for budgeting and cost management in Slovakia. For a example: Cenkros 4, Kalkulus and Odis and so on. These tools can not be considered as full software tools supporting information modeling of buildings.

Implementation of information modeling of buildings in Slovakia is weak because overall there is a great degree of awareness and reluctance to learn with new knowledge. The overall state of implementation in Slovakia is in its early stages. Interesting findings on the state of implementation of BIM in Slovakia brought research carried out by Mesároš, Selín and Mandičák in 2016 under the title Identifying Approaches to Cost Management in Slovak Construction Enterprises. Research has focused primarily on the use of BIM technologies to reduce the total costs of construction enterprises [16].

Research has produced the following findings. It was assumed that there was a direct link between the size of the construction company and the use of BIM technology, but the results rejected this assumption. The survey showed the greater impact of BIM technologies on cost reducing in small enterprises. Accordint to Mesaros, Selin and Mandica, the reason it could be the lower rate of use of BIM technologies in the construction company, or the fact that BIM technology has a significant impact on the reduction of the total cost of construction enterprises, different from the participant in the construction project. BIM technology is mainly used by designers and architects. As part of the research, these participants were smaller enterprises and therefore no significant impact on the size of the construction companies can be confirmed and the use of BIM technologies does not have a significant impact on the reduction of the total costs of the construction enterprises, apart from the size of the construction enterprises [16].

The second research hypothesis examined was to investigate the assumption that the exploitation of BIM technology had a significant impact on the reduction of the total cost in construction enterprises, apart from the majority owner of the construction enterprises. But this hypothesis was also rejected. However, research has confirmed the hypothesis: The exploitation of BIM technology has a significant impact on the total cost 
reducing in construction projects in a different way from the participant in the construction project. Based on the survey results, the designer and architect have the greatest impact on the use of BIM technology on the total cost of construction projects, followed by major contractors, subcontractors and developers [16]. Even in this area, however, profitability is important, as it say other surveys [17]. That is why we need to look for another link to this.

\section{Future research}

Knowledge of structure and costs' dynamic in construction of company is a starting point for effective price making. Constructing itself is characterized by high amount of input data's, information, which has to be taken into account in whole construction process. BIM allows to work with information briefly and effectively. Pricing of civil engineering production does not use information modelling of buildings. Next research goal is to map out and identification current state of civil engineering pricing in Slovakia and define suppositions and barriers of pricing in BIM. Subsequently, based on realized researches and acquired knowledge from Slovakia and foreign countries, suggest and develop exact method of planning economical and costs parameters for civil engineering pricing in information modelling of building.

\section{Conclusion}

BIM technology offered a lot of functionality and it s very helpful tool in construction project management. Cost management is very important part of construction project management. Accurate and information based cost management may have an serious impact on the success of construction project. BIM technology has a lot of functionality, includes cost management too. Research tried to make an overview of using BIM technology and cost management tools at home and abroad. Research also point to new research opportunities and to identify research issues in this area. Exploitation of BIM technology has a different level in worldeide countries. The overall state of implementation in Slovakia is in its early stages. Comparing with other countries is quite interesting. Exploitation of BIM technology is better in countries as United Kingdom, New Zealand and so on. In these countries, the issue of BIM is mainly incorporated into legislation. This is often the reason why the use of BIM is to such an extent. The inter-country survey has also highlighted the specific software options and practices that are being used. The survey opened up other issues that need to be addressed.

\section{Acknowledgement}

The paper presents a partial research results of project VEGA 1/0828/17 "Research and application of knowledge-based systems for modeling cost and economic parameters in Building Information Modeling".

\section{References}

[1] LU, W., PENG, Y., SHEN, Q., LING, H.: Generic model for measuring benefits of BIM as a learning tool in construction tasks, Journal of Construction Engineering and Management, Vol.139, No.2, pp. 195213, 2013.

[2] From 3D to 5D, [Online], Available: http://www.axdst udio.com/portfolio/all-the-bim-dimensions/ (28/04/2018).

[3] KROS: Ako správne a objektívne ocenit' stavebnú zákazku, 2017, [Online], Available: https://www.kros. sk/blog/ako-spravne-a-objektivne-ocenit-stavebnuzakazku-65308 (28/04/2018).

[4] STANLEY, R., THURNELL, D.: The Benefits of, and Barriers to, Implementation of 5D BIM for Quatity Surveying in New, Australasian Journal of Construction Economics and Building, Vol.14, No.1, pp. 105-117, 2014.

[5] PROJECT COST ESTIMATION: A Practical Guide, [Online], Available: https://www.aproplan.com/blog/e fficiency/project-cost-estimation-practical-guide. (28/04/2018).

[6] MASTERSPEC: New Zealand National BIM Survey 2012. [Online], Available: http://www.masterspec.co. nz/news/reports-1243.htm (28/04/2018).

[7] AUSTRALIAN INSTITUTE OF ARCHITECTS: Towards Integration, National Building Information Modelling (BIM), 2009. Guidelines and Case Studies, 2009. http://www.construction-

innovation.info/images -

/pdfs/Brochures/Towards_Integration_Brochure_1704 09b.pdf (28/04/2018)

[8] BOON, J., PRIGG, C.: Evolution of quantity surveying practice in the use of BIM - the New Zealand experience, 2012. In Management of Construction: Research to Practice Proceedings, Joint CIB International Symposium of W055, W065, W089, W118, TG76, TG78, TG81 \& TG84, Montreal, Canada; pp.84-98, 2012.

[9] KARAMAENA, D., DOMINGO, N.: 5D building information modelling in the New Zealand quantity surveying profession, 2014. In Proceedings of the 2014 CIB W55/65/89/92/96/102/117 \& TG72/81/83 International Conference on Construction in a Changing World International Conference, Colombo, Sri Lanka

[10] HARRISON, C., THURNELL, D.: BIM implementation in a New Zealand consulting quantity surveying practice, International journal of construction supply chain management, Vol.5, No1., pp. 1-15, 2015.

[11] SMITH, P.: BIM \& project cost management implementation issues \& creative solutions, 2013. In: Diamond Congress Ltd. Proceedings Creative Construction Conference 2013, pp.774-756, 2013.

[12] JÓHANNESSON E, I.: Implementation of BIM, 2009. [Online], Danish Experience from Icelandic P 
erspective, Available: http://bim.is/wpcontent/uploads/2015/06/Implementation_of_BIM_ EIJ1.pdf (28/04/2018)

[13] ČERNÝ, M. et al.: BIM Příručka. 2014. [Online]. Odborná rada pro BIM o.s. ISBN 978-80-260-52975. https://issuu.com/rozpoctakacallida/docs/bimprirucka-4projects (28/04/2018) (Original in Czech)

[14] EADIE, R., BROWNE, M., ODEYINKA, H., MCKEOWN, C., MCNIFF, S.: BIM implementation throughout the UK construction project lifecycle: An analysis, Automation in Construction, Vol.2013, No.36, pp. 14-154, 2016.

[15] GOBAU, T.: Construction Software Trends of 2016. Retrospective, 2016. [Online], Available: https://ww w.aproplan.com/blog/efficiency/retrospective-2016construction-software-trends (28/04/2018).

[16] MESÁROŠ, P.; SELÍN, J.; MANDIČÁK, T. Identifikácia prístupov $k$ riadeniu nákladov v slovenských stavebných podnikoch, Technical university of Kosice, pp. 195-198, 2016. (Original in Slovak)

[17] RADZISZEWSKA-ZIELINA, E.: Analysis of the Profitability of Investment in Renewable Energy Sources on the Example of A Semi-Detached House, E3S Web of Conferences - $1^{\text {st }}$ International Conference on the Sustainable Energy and Environment Development, Vol.10, 2016.

\section{Review process}

Single-blind peer review process. 